\title{
KAJIAN MUTU IKAN CAKALANG (Katsuwonus pelamis L) SEGAR DI PASAR BERSEHATI MANADO
}

\author{
Nashadin Daud, I Ketut Suwetja, Lita A.D.Y. Montolalu \\ Fakultas Perikanan dan Ilmu Kelautan, Universitas Sam Ratulangi, Manado, Sulawesi Utara.
}

\begin{abstract}
ABSTRAK
Sampel penelitian ini diambil mengikuti proses penanganan ikan Cakalang (Katsuwonus pelamis L) di pasar Bersehati kota Manado. Sebelum dipajang untuk dijual, ikan diberi perlakuan pendinginan dengan cara penambahan es untuk melihat dampak proses terhadap mutu ikan sampai ke konsumen. Untuk itu kami melakukan penelitian tentang kajian mutu ikan Cakalang di Pasar Bersehati kota Manado. Mengkaji mutu ikan Cakalang segar yang dijual di pasar Bersehati kota Manado menggunakan perlakuan yaitu pada jam 06.00-07.00, jam 11.00-12.00 dan jam 16.00-17.00, dan pedagang yang terdiri dari pedagang 1, pedagang 2 dan pedagang 3 . Ulangan dalam penelitian ini adalah 3 kali pengambilan sampel yaitu hari pertama, kedua dan ketiga. Penelitian ini menggunakan metode deskriptif dan dianalisis menggunakan Microsoft excel untuk mendapatkan nilai rata-rata.

Hasil Penelitian adalah sebagai berikut: nilai rata-rata $\mathrm{pH}$ ikan Cakalang segar di pasar Bersehati sampel untuk pedagang 1, 2 dan 3 pada jam $06.00-07.00$ adalah 5,37. Nilai rata-rata $\mathrm{pH}$ sampel untuk pedagang 1, 2 dan 3 pada pengambilan ikan Cakalang jam 12.00-13.00 adalah 5,46 dan nilai rata-rata $\mathrm{pH}$ sampel untuk pedagang 1, 2 dan 3 pada jam 16.00-17.00 adalah 5,43. Data ini menunjukkan bahwa pengambilan sampel jam 06.00-07.00, 11.00-12.00, dan 16.00-17.00 mendapatkan nilai yang cukup rendah. Ini berarti dari nilai $\mathrm{pH}$, ikan sampel masih layak dikonsumsi. Nilai rata-rata TVB-N ikan Cakalang sampel untuk pedagang 1, 2 dan 3 pada jam 06.00-07.00 adalah 10,82 mgN/100g. Nilai rata-rata TVB-N sampel untuk pedagang 1, 2 dan 3 pada pengambilan ikan Cakalang jam 12.00-13.00 adalah 13,25 mg-N/100g dan nilai rata-rata TVB-N sampel untuk pedagang 1,2 dan 3 pada jam 16.00-17.00 adalah $21.81 \mathrm{mg}-\mathrm{N} / 100 \mathrm{~g}$. Data ini menunjukkan bahwa pengambilan sampel jam 06.0007.00, 11.00-12.00 dan 16.00-17.00 mendapatkan nilai yang cukup rendah, lebih rendah dari nilai ambang batas TVB-N untuk ikan segar yaitu $30 \mathrm{mg} \mathrm{N} / 100 \mathrm{~g}$ sampel. Ini berarti dari nilai TVB-N, ikan sampel masih layak dikonsumsi. Nilai organoleptik yaitu mata, insang, lendir permukaan badan, daging (warna dan permukaan), dan tekstur terdapat korelasi positif yaitu nilai pada ketiga pedagang terdapat pada pengambilan sampel jam 06.00-07.00, selanjutnya menurun pada pengambilan sampel jam 11.00 12.00 dan 16.00-17.00, walaupun demikian nilai organoleptik masih masuk kategori ikan bermutu segar dan agak segar.
\end{abstract}

Kata kunci: Ikan Cakalang (Katsuwonus pelamis L), kajian mutu, pH, TVB-N, organoleptik.

\section{PENDAHULUAN}

Ikan merupakan salah satu sumber protein hewani yang mempunyai nilai gizi tinggi. Rata-rata komposisi kimia ikan terdiri dari air $70-80 \%$, protein $15-24 \%$, lemak $0,1-$ $2,2 \%$, karbohidrat $0,0-1,0 \%$ dan mineral $0,8-$ 2\% (Suwetja 2011).

Banyak faktor yang menentukan kecepatan penurunan terhadap kesegaran ikan. Suhu penyimpanan memainkan peranan penting pada ikan setelah mati. Penggunaan suhu rendah sekitar $0^{\circ} \mathrm{C}$ setelah ikan mati dapat memperpanjang masa kejang (rigor mortis), dapat menekan kegiatan enzimatis, bakterial, kimiawi dan perubahan organoleptik. Mutu ikan adalah nilai-nilai tertentu yang diinginkan pada suatu produk. Mutu ikan antara lain ditentukan oleh komposisi kimia, $\mathrm{pH}$, Total Volatile Base
Nitrigen (TVB-N) dan nilai organoleptik dari ikan (Seokarno, 1985).

Suhu penyimpanan merupakan salah satu faktor yang mempunyai peranan penting pada penurunan mutu ikan setelah mati. Selain itu ialah sanitasi, jangka waktu penanganan dan penyimpanan. Semakin lama waktu yang digunakan maka semakin menurun mutunya (Suwetja, 1992).

$\mathrm{pH}$ daging ikan akan mengalami penurunan hanya sampai batas tertentu yaitu sekitar $\mathrm{pH}$ 5,5. Penentuan kadar Total Volatile Base Nitrogen (TVB-N) adalah merupakan metode uji kesegaran bakteriologis atau metode pengukuran hasil uji bakterial pada ikan mati setelah melewati fase rigor mortis dan memasuki fase autolysis dan pembusukan dimana proses kerja enzim pada tubuh ikan lebih aktif dalam merombak senyawa-senyawa yang kompleks menjadi senyawa-senyawa yang 
sederhana. Senyawa-senyawa inilah yang memberikan kesan daging ikan busuk. Menurut Metusalach $d k k$. (2012), penentuan nilai TNB-N bertujuan untuk mengukur jumlah basa-basa menguap dari dalam sampel. Nilai TVB-N sangat erat kaitannya dengan proses kemunduran mutu ikan. Semakin tinggi nilai TVB-N pada umumnya semakin menurun mutu ikan. Nilai batas kesegaran bakterial ikan dengan uji kadar TVB-N sebesar $30 \mathrm{mg} \mathrm{N} / 100$ g daging (Suwetja 1992).

\section{METODOLOGI PENELITIAN}

Peralatan yang akan digunakan dalam pengujian $\mathrm{pH}$ dan TVB-N antara lain $\mathrm{pH}$ meter, oven, timbangan analitik, corong, blender, gelas ukur, cawan conway, mikro buret, inkubator, mortar dan kertas saring. Sedangkan alat untuk pengujian organoleptik antara lain, score sheet, dan tissue. Bahan baku yang digunakan dalam penelitian ini adalah ikan Cakalang, dengan berat rata-rata $1 \mathrm{~kg}$. Brome cresol green, metil red, asam trikloroasetat 7,5\%, kalium karbonat jenuh, $\mathrm{HCl} 0,02 \mathrm{~N}$, akuades, asam borat $1 \%$, dan vaselin.

penentuan $\mathrm{pH}$ dapat dilakukan dengan menggunakan $\mathrm{pH}$ meter. Analisis Total Volatile Base Nitrogen (TVB-N) menggunakan metode Conway. Pengujian organoleptik yaitu pengujian terhadap kondisi fisik ikan, mata, insang, lendir, daging, bau dan tekstur.

\section{HASIL DAN PEMBAHASAN}

Nilai rata-rata $\mathrm{pH}$ ikan Cakalang sampel untuk pedagang 1,2 dan 3 pada jam 06.0007.00 adalah 5,37. Nilai rata-rata $\mathrm{pH}$ sampel untuk pedagang 1, 2 dan 3 pada pengambilan ikan Cakalang jam 12.00-13.00 adalah 5,46 dan nilai rata-rata sampel untuk pedagang 1,2 dan 3 adalah 5,43.

Data $\mathrm{pH}$ menunjukan bahwa pengambilan sampel jam 06.00-07.00, 11.0012.00 dan $16.00-17.00$ mendapatkan nilai yang cukup rendah, lebih rendah dari nilai $\mathrm{pH}$ netral yaitu 7. Ini berarti dari nilai $\mathrm{pH}$ ikan sampel masih layak dikonsumsi.

Nilai rata-rata TVB-N ikan Cakalang sampel untuk pedagang 1,2 dan 3 pada jam 06.00-07.00 adalah 10,82 mg-N/100g. Nilai rata-rata TVB-N sampel untuk pedagang 1, 2 dan 3 pada pengambilan ikan Cakalang jam 12.00-13.00 adalah $13,25 \mathrm{mg}-\mathrm{N} / 100 \mathrm{~g}$ dan nilai rata-rata sampel untuk pedagang 1,2 dan 3 adalah $21,81 \mathrm{mg}-\mathrm{N} / 100 \mathrm{~g}$.

Tabel 1. Data pH ikan Cakalang segar pada waktu pengambilan sampel dari pedagang yang berbeda.

\begin{tabular}{|c|c|c|c|c|c|c|c|}
\hline \multicolumn{2}{|c|}{$\begin{array}{l}\text { Pengambilan } \\
\text { sampel } \\
\text { pedagang }\end{array}$} & \multicolumn{3}{|c|}{ Ulangan } & \multirow[t]{2}{*}{$\Sigma$} & \multirow[t]{2}{*}{$\overline{\mathbf{X}}$} & \multirow[t]{2}{*}{ SD } \\
\hline (A) & (B) & 1 & 2 & 3 & & & \\
\hline \multirow[t]{3}{*}{$\mathrm{A} 1$} & B1 & 5.2 & 5.2 & 5.4 & 15.8 & 5.26 & 0.11 \\
\hline & B2 & 5.4 & 5.4 & 5.5 & 16.3 & 5.43 & 0.05 \\
\hline & B3 & 5.4 & 5.4 & 5.5 & 16.3 & 5.43 & 0.05 \\
\hline$\Sigma$ & & & & & & 16.12 & \\
\hline$\overline{\mathbf{X}}$ & & & & & & 5.37 & \\
\hline \multirow[t]{3}{*}{$\mathrm{A} 2$} & B1 & 5.4 & 5.3 & 5.4 & 16.1 & 5.36 & 0.05 \\
\hline & $\mathrm{B} 2$ & 5.4 & 5.5 & 5.4 & 16.3 & 5.43 & 0.05 \\
\hline & B3 & 5.4 & 5.9 & 5.5 & 16.8 & 5.6 & 0.26 \\
\hline$\Sigma$ & & & & & & 16.39 & \\
\hline$\overline{\mathbf{X}}$ & & & & & & 5.46 & \\
\hline \multirow[t]{3}{*}{ A3 } & B1 & 5.3 & 5.4 & 5.4 & 16.1 & 5.36 & 0.05 \\
\hline & $\mathrm{B} 2$ & 5.5 & 5.4 & 5.4 & 16.3 & 5.43 & 0.05 \\
\hline & B3 & 5.6 & 5.5 & 5.4 & 16.5 & 5.5 & 0.10 \\
\hline$\Sigma$ & & & & & & 16.29 & \\
\hline$\overline{\mathbf{X}}$ & & & & & & 5.43 & \\
\hline
\end{tabular}

Tabel 2. Data TVB-N (mg N/100g sampel) ikan Cakalang segar pada waktu pengambilan sampel dari pedagang yang berbeda.

\begin{tabular}{|c|c|c|c|c|c|c|c|}
\hline \multicolumn{2}{|c|}{$\begin{array}{c}\text { Pengambilan } \\
\text { sampel } \\
\text { pedagang }\end{array}$} & \multicolumn{3}{|c|}{ Ulangan } & \multirow[t]{2}{*}{$\Sigma$} & \multirow[t]{2}{*}{$\overline{\mathbf{X}}$} & \multirow[t]{2}{*}{ SD } \\
\hline (A) & (B) & 1 & 2 & 3 & & & \\
\hline \multirow[t]{3}{*}{ A1 } & B1 & 16.8 & 8.4 & 8.4 & 33.6 & 11.20 & 4.84 \\
\hline & B2 & 8.4 & 15.4 & 8.4 & 64.3 & 21.43 & 8.02 \\
\hline & B3 & 8.4 & 13.4 & 16.8 & 38.6 & 12.88 & 4.22 \\
\hline$\Sigma$ & & & & & & 45.50 & \\
\hline$\overline{\mathbf{X}}$ & & & & & & 15.16 & \\
\hline \multirow[t]{3}{*}{ A2 } & B1 & 8.4 & 10.1 & 8.4 & 26.9 & 8.96 & 4.37 \\
\hline & B2 & 16.8 & 11.8 & 1.8 & 30.4 & 15.12 & 7.63 \\
\hline & B3 & 13.4 & 8.4 & 25.2 & 47.0 & 15.68 & 8.62 \\
\hline$\Sigma$ & & & & & & 39.76 & \\
\hline$\overline{\mathbf{X}}$ & & & & & & 13.25 & \\
\hline \multirow[t]{3}{*}{ A3 } & B1 & 25.2 & 25.2 & 16.8 & 67.2 & 22.40 & 4.84 \\
\hline & B2 & 16.6 & 26.9 & 18.5 & 62.0 & 20.65 & 5.47 \\
\hline & B3 & 16.8 & 25.2 & 25.2 & 67.2 & 22.40 & 4.84 \\
\hline$\Sigma$ & & & & & & 65.45 & \\
\hline$\overline{\mathbf{X}}$ & & & & & & 21.81 & \\
\hline
\end{tabular}

Data TVB-N menunjukan bahwa pada pengambilan sampel jam 06.00-07.00, 11.0012.00 dan 16.00-17.00 mendapatkan nilai yang cukup rendah, lebih rendah dari nilai TVB-N netral yaitu 7. Ini berarti dari nilai TVB-N, ikan sampel masih layak dikonsumsi.

Nilai rata-rata organoleptik mata ikan Cakalang sampel untuk pedagang 1, 2 dan 3 pada jam 06.00-07.00 adalah 7,74. Nilai ratarata organoleptik sampel untuk pedagang 1, 2 dan 3 pada pengambilan ikan Cakalang jam 12.00-13.00 adalah 6,52. Nilai rata-rata sampel 
untuk pedagang 1,2 dan 3 pada jam 16.00 17.00 adalah 5,96.

Tabel 3. Data organoleptik pada mata ikan Cakalang segar pada waktu pengambilan sampel dari pedagang yang berbeda.

\begin{tabular}{|c|c|c|c|c|c|c|c|}
\hline \multicolumn{2}{|c|}{$\begin{array}{c}\text { Pengambilan } \\
\text { sampel } \\
\text { pedagang }\end{array}$} & \multicolumn{3}{|c|}{ Ulangan } & \multirow[t]{2}{*}{$\Sigma$} & \multirow[t]{2}{*}{$\overline{\mathbf{X}}$} & \multirow[t]{2}{*}{ SD } \\
\hline (A) & (B) & 1 & 2 & 3 & & & \\
\hline \multirow[t]{3}{*}{ A1 } & B1 & 7.80 & 7.60 & 7.53 & 22.93 & 7.64 & 0.14 \\
\hline & B2 & 8.20 & 8.40 & 7.50 & 24.10 & 8.03 & 0.47 \\
\hline & B3 & 7.80 & 7.60 & 7.26 & 22.66 & 7.55 & 0.27 \\
\hline$\Sigma$ & & & & & & 23.22 & \\
\hline$\overline{\mathbf{X}}$ & & & & & & 7.74 & \\
\hline \multirow[t]{3}{*}{ A2 } & B1 & 6.50 & 6.40 & 6.60 & 19.50 & 6.50 & 0.10 \\
\hline & B2 & 6.86 & 6.53 & 6.80 & 20.19 & 6.73 & 0.17 \\
\hline & B3 & 6.20 & 6.33 & 6.46 & 18.99 & 6.33 & 0.13 \\
\hline$\Sigma$ & & & & & & 19.56 & \\
\hline$\overline{\mathbf{X}}$ & & & & & & 6.52 & \\
\hline \multirow[t]{3}{*}{ A3 } & B1 & 6.00 & 6.26 & 6.20 & 18.46 & 6.15 & 0.13 \\
\hline & B2 & 6.40 & 6.06 & 5.33 & 17.79 & 5.93 & 0.54 \\
\hline & B3 & 6.30 & 5.80 & 5.80 & 17.90 & 5.80 & 0.28 \\
\hline$\Sigma$ & & & & & & 17.88 & \\
\hline$\overline{\mathbf{X}}$ & & & & & & 5.96 & \\
\hline
\end{tabular}

Data di atas organoleptik mata tersebut menunjukkan bahwa pengambilan sampel jam 06.00-07.00, 11.00-12.00 dan 16.00-17.00 mendapatkan nilai di atas angka 6 , lebih rendah dari nilai organoleptik netral yaitu 7 . Ini berarti dari nilai organoleptik mata, ikan sampel masih layak dikonsumsi.

Tabel 4. Data organoleptik pada insang ikan Cakalang segar pada pengambilan sampel dari pedagang yang berbeda.

\begin{tabular}{|c|c|c|c|c|c|c|c|}
\hline \multicolumn{2}{|c|}{$\begin{array}{c}\text { Pengambilan } \\
\text { sampel } \\
\text { pedagang }\end{array}$} & \multicolumn{3}{|c|}{ Ulangan } & \multirow[t]{2}{*}{$\Sigma$} & \multirow[t]{2}{*}{$\overline{\mathbf{x}}$} & \multirow[t]{2}{*}{ SD } \\
\hline (A) & (B) & 1 & 2 & 3 & & & \\
\hline \multirow[t]{3}{*}{ A1 } & B1 & 7.60 & 7.60 & 7.53 & 22.73 & 7.57 & 0.04 \\
\hline & B2 & 8.40 & 8.40 & 7.60 & 24.40 & 8.40 & 0.46 \\
\hline & B3 & 7.80 & 7.80 & 7.53 & 23.13 & 7.71 & 0.15 \\
\hline$\Sigma$ & & & & & \multicolumn{3}{|c|}{23.68} \\
\hline$\overline{\mathbf{x}}$ & & & & & & 7.89 & \\
\hline \multirow[t]{3}{*}{$\mathrm{A} 2$} & B1 & 6.20 & 6.60 & 6.60 & 19.4 & 6.46 & 0.23 \\
\hline & B2 & 6.60 & 6.46 & 6.33 & 19.39 & 6.46 & 0.13 \\
\hline & B3 & 6.06 & 6.13 & 6.40 & 18.59 & 6.13 & 0.17 \\
\hline$\Sigma$ & & & & & \multicolumn{3}{|c|}{19.05} \\
\hline$\overline{\mathbf{X}}$ & & & & & \multicolumn{3}{|c|}{6.35} \\
\hline \multirow[t]{3}{*}{$\mathrm{A} 3$} & B1 & 6.00 & 6.33 & 6.20 & 18.53 & 6.17 & 0.16 \\
\hline & B2 & 6.33 & 5.86 & 5.66 & 17.85 & 5.96 & 0.34 \\
\hline & B3 & 5.73 & 5.33 & 5.33 & 16.39 & 5.46 & 0.23 \\
\hline$\Sigma$ & & & & & \multicolumn{3}{|c|}{17.59} \\
\hline$\overline{\mathbf{X}}$ & & & & & & 5.86 & \\
\hline
\end{tabular}

Nilai rata-rata organoleptik insang ikan Cakalang sampel untuk pedagang 1, 2 dan 3 pada jam 06.00-07.00 adalah 7,89. Nilai rata- rata organoleptik sampel untuk pedagang 1,2 dan 3 pada pengambilan jam $12.00-13.00$ adalah 6,35. Nilai rata-rata sampel untuk pedagang 1, 2 dan 3 pada jam 16.00-17.00 adalah 5,86 .

Data organoleptik insang menunjukan bahwa pengambilan sampel jam 06.00-07.00, 11.00-12.00 dan 16.00-17.00 mendapatkan nilai di atas angka 6 , lebih rendah dari nilai organoleptik netral yaitu 7. Ini berarti dari nilai organoleptik insang, ikan sampel masih layak dikonsumsi.

Nilai rata-rata organoleptik lendir ikan Cakalang sampel untuk pedagang 1, 2 dan 3 pada jam 06.00-07.00 adalah 7,44 . Nilai ratarata organoleptik sampel untuk pedagang 1,2 dan 3 pada pengambilan ikan Cakalang jam 12.00-13.00 adalah 6,35. Nilai rata-rata sampel untuk pedagang 1, 2 dan 3 pada jam 16.0017.00 adalah 5,87 .

Tabel 5. Data organoleptik pada lendir ikan Cakalang segar pada waktu pengambilan sampel dari pedagang yang berbeda.

\begin{tabular}{|c|c|c|c|c|c|c|c|}
\hline \multicolumn{2}{|c|}{$\begin{array}{l}\text { Pengambilan } \\
\text { sampel } \\
\text { pedagang }\end{array}$} & \multicolumn{3}{|c|}{ Ulangan } & \multirow[t]{2}{*}{$\Sigma$} & \multirow[t]{2}{*}{$\overline{\mathbf{X}}$} & \multirow[t]{2}{*}{ SD } \\
\hline (A) & (B) & 1 & 2 & 3 & & & \\
\hline \multirow[t]{3}{*}{ A1 } & B1 & 7.60 & 7.40 & 7.26 & 22.26 & 7.42 & 0.17 \\
\hline & B2 & 7.60 & 7.40 & 7.33 & 22.33 & 7.44 & 0.14 \\
\hline & B3 & 7.60 & 7.26 & 7.53 & 22.39 & 7.46 & 0.17 \\
\hline$\Sigma$ & & & & & \multicolumn{3}{|c|}{22.32} \\
\hline \multirow{4}{*}{$\frac{\mathbf{X}}{\mathrm{A} 2}$} & & & & & \multicolumn{3}{|c|}{7.44} \\
\hline & B1 & 6.20 & 6.50 & 6.66 & 19.36 & 6.45 & 0.23 \\
\hline & B2 & 6.46 & 6.40 & 6.60 & 19.46 & 6.48 & 0.10 \\
\hline & B3 & 6.00 & 6.13 & 6.24 & 18.37 & 6.12 & 0.12 \\
\hline$\Sigma$ & & & & & \multicolumn{3}{|c|}{19.05} \\
\hline$\overline{\mathbf{X}}$ & & & & & \multicolumn{3}{|c|}{6.35} \\
\hline \multirow[t]{3}{*}{ A3 } & B1 & 5.86 & 6.26 & 6.10 & 18.22 & 6.07 & 0.20 \\
\hline & B2 & 5.66 & 5.66 & 5.60 & 16.92 & 5.64 & 0.03 \\
\hline & B3 & 5.66 & 5.40 & 6.66 & 17.72 & 5.9 & 0.66 \\
\hline$\Sigma$ & & & & & \multicolumn{3}{|c|}{17.61} \\
\hline$\overline{\mathbf{x}}$ & & & & & \multicolumn{3}{|c|}{5.87} \\
\hline
\end{tabular}

Data organoleptik lendir menunjukkan bahwa pengambilan sampel jam 06.00-07.00, 11.00-12.00 dan 16.00-17.00 mendapatkan nilai di atas angka 6 , lebih rendah dari nilai organoleptik netral yaitu 7. Ini berarti dari nilai organoleptik lendir, ikan sampel masih layak dikonsumsi.

Nilai rata-rata organoleptik daging ikan Cakalang sampel untuk pedagang 1, 2 dan 3 pada jam 06.00-07.00 adalah 7,59. Nilai ratarata organoleptik sampel untuk pedagang 1,2 dan 3 pada pengambilan jam 12.00-13.00 adalah 6,51. Nilai rata-rata sampel untuk 
pedagang 1, 2 dan 3 pada jam 16.00-17.00 adalah 5,91 .

Tabel 6. Data organoleptik pada daging ikan Cakalang segar pada waktu pengambilan sampel dari pedagang yang berbeda.

\begin{tabular}{|c|c|c|c|c|c|c|c|}
\hline \multicolumn{2}{|c|}{$\begin{array}{c}\text { Pengambilan } \\
\text { sampel } \\
\text { pedagang }\end{array}$} & \multicolumn{3}{|c|}{ Ulangan } & \multirow[t]{2}{*}{$\Sigma$} & \multirow[t]{2}{*}{$\overline{\mathbf{X}}$} & \multirow[t]{2}{*}{ SD } \\
\hline (A) & (B) & 1 & 2 & 3 & & & \\
\hline \multirow[t]{3}{*}{ A1 } & B1 & 8.46 & 7.40 & 7.53 & 23.39 & 7.79 & 0.57 \\
\hline & B2 & 7.60 & 7.60 & 7.40 & 22.60 & 7.53 & 0.11 \\
\hline & B3 & 7.33 & 7.53 & 7.50 & 22.36 & 7.45 & 0.10 \\
\hline$\Sigma$ & & & & & & 22.77 & \\
\hline$\overline{\mathbf{X}}$ & & & & & & 7.59 & \\
\hline \multirow[t]{3}{*}{$\mathrm{A} 2$} & $\mathrm{~B} 1$ & 6.20 & 6.6 & 6.60 & 19.40 & 6.46 & 0.20 \\
\hline & B2 & 6.53 & 6.53 & 6.93 & 19.99 & 6.66 & 0.23 \\
\hline & B3 & 6.13 & 6.66 & 6.46 & 19.25 & 6.41 & 0.26 \\
\hline$\Sigma$ & & & & & & 19.53 & \\
\hline$\overline{\mathbf{X}}$ & & & & & & 6.51 & \\
\hline \multirow[t]{3}{*}{ A3 } & B1 & 6.06 & 6.00 & 6.46 & 18.52 & 6.17 & 0.25 \\
\hline & B2 & 5.86 & 5.60 & 5.80 & 17.26 & 5.75 & 0.13 \\
\hline & B3 & 5.80 & 5.80 & 5.86 & 17.46 & 5.82 & 0.03 \\
\hline$\Sigma$ & & & & & & 17.74 & \\
\hline$\overline{\mathbf{X}}$ & & & & & & 5.91 & \\
\hline
\end{tabular}

Data organoleptik daging menunjukkan bahwa pengambilan sampel jam 06.00-07.00, 11.00-12.00 dan 16.00-17.00 mendapatkan nilai di atas angka 6 , lebih rendah dari nilai organoleptik netral yaitu 7. Ini berarti dari nilai organoleptik daging, ikan sampel masih layak dikonsumsi.

Tabel 7. Data organoleptik pada bau ikan Cakalang segar pada waktu pengambilan sampel dari pedagang yang berbeda.

\begin{tabular}{|c|c|c|c|c|c|c|c|}
\hline \multicolumn{2}{|c|}{$\begin{array}{c}\text { Pengambilan } \\
\text { sampel } \\
\text { pedagang }\end{array}$} & \multicolumn{3}{|c|}{ Ulangan } & \multirow[t]{2}{*}{$\Sigma$} & \multirow[t]{2}{*}{$\overline{\mathbf{X}}$} & \multirow[t]{2}{*}{ SD } \\
\hline (A) & (B) & 1 & 2 & 3 & & & \\
\hline \multirow[t]{3}{*}{$\mathrm{A} 1$} & $\mathrm{~B} 1$ & 7.40 & 7.53 & 7.53 & 22.46 & 7.48 & 0.07 \\
\hline & B2 & 7.60 & 7.50 & 7.46 & 22.56 & 7.52 & 0.07 \\
\hline & B3 & 7.66 & 7.56 & 7.46 & 22.68 & 7.56 & 0.10 \\
\hline$\Sigma$ & & & & & & 22.56 & \\
\hline$\overline{\mathbf{X}}$ & & & & & & 7.52 & \\
\hline \multirow[t]{3}{*}{ A2 } & B1 & 6.60 & 6.70 & 6.66 & 19.96 & 6.65 & 0.07 \\
\hline & B2 & 6.60 & 6.46 & 6.60 & 19.66 & 6.55 & 0.08 \\
\hline & B3 & 6.20 & 6.46 & 6.53 & 19.19 & 6.39 & 0.17 \\
\hline$\Sigma$ & & & & & & 19.59 & \\
\hline$\overline{\mathbf{X}}$ & & & & & & 6.53 & \\
\hline \multirow[t]{3}{*}{ A3 } & B1 & 5.93 & 6.20 & 6.66 & 18.79 & 6.26 & 0.36 \\
\hline & B2 & 6.20 & 5.93 & 5.80 & 17.93 & 5.97 & 0.20 \\
\hline & B3 & 5.60 & 5.46 & 5.46 & 16.52 & 5.50 & 0.08 \\
\hline$\underline{\Sigma}$ & & & & & & 17.73 & \\
\hline$\overline{\mathbf{X}}$ & & & & & & 5.91 & \\
\hline
\end{tabular}

Nilai rata-rata organoleptik bau ikan Cakalang sampel untuk pedagang 1, 2 dan 3 pada jam 06.00-07.00 adalah 7,52. Nilai ratarata organoleptik sampel untuk pedagang 1, 2 dan 3 pada pengambilan jam 12.00-13.00 adalah 6,53. Nilai rata-rata sampel untuk pedagang 1, 2 dan 3 pada jam 16.00-17.00 adalah 5,91.

Data organoleptik bau menunjukkan bahwa pengambilan sampel jam 06.00-07.00, 11.00-12.00 dan 16.00-17.00 mendapatkan nilai di atas angka 6 , lebih rendah dari nilai organoleptik netral yaitu 7. Ini berarti dari nilai organoleptik bau, ikan sampel masih layak dikonsumsi.

Nilai rata-rata Organoleptik tekstur ikan Cakalang sampel untuk pedagang 1, 2 dan 3 pada jam 06.00-07.00 adalah 7,59. Nilai ratarata organoleptik sampel untuk pedagang 1, 2 dan 3 pada pengambilan jam 12.00-13.00 adalah 6,57. Nilai rata-rata sampel untuk pedagang 1,2 dan 3 pada jam 16.00-17.00 adalah 6,05 .

Tabel 8. Data organoleptik pada tekstur ikan Cakalang segar pada waktu pengambilan sampel dari pedagang yang berbeda.

\begin{tabular}{|c|c|c|c|c|c|c|c|}
\hline \multicolumn{2}{|c|}{$\begin{array}{c}\text { Pengambilan } \\
\text { sampel } \\
\text { pedagang }\end{array}$} & \multicolumn{3}{|c|}{ Ulangan } & \multirow[t]{2}{*}{$\Sigma$} & \multirow[t]{2}{*}{$\overline{\mathbf{X}}$} & \multirow[t]{2}{*}{ SD } \\
\hline (A) & (B) & 1 & 2 & 3 & & & \\
\hline \multirow[t]{3}{*}{ A1 } & B1 & 7.53 & 7.60 & 7.53 & 22.66 & 7.55 & 0.04 \\
\hline & B2 & 7.80 & 7.80 & 7.20 & 22.80 & 7.63 & 0.34 \\
\hline & B3 & 7.66 & 7.80 & 7.46 & 22.92 & 7.64 & 0.17 \\
\hline$\Sigma$ & & & & & & 22.79 & \\
\hline$\overline{\mathbf{X}}$ & & & & & & 7.59 & \\
\hline \multirow[t]{3}{*}{$\mathrm{A} 2$} & B1 & 6.10 & 6.80 & 6.66 & 19.56 & 6.52 & 0.37 \\
\hline & B2 & 6.66 & 6.60 & 6.53 & 19.79 & 6.59 & 0.06 \\
\hline & B3 & 6.66 & 6.60 & 6.60 & 19.86 & 6.62 & 0.03 \\
\hline$\Sigma$ & & & & & & 19.73 & \\
\hline$\overline{\mathbf{X}}$ & & & & & & 6.57 & \\
\hline \multirow[t]{3}{*}{ A3 } & B1 & 6.26 & 6.40 & 6.46 & 19.12 & 6.37 & 0.10 \\
\hline & B2 & 6.33 & 5.80 & 5.80 & 17.93 & 5.97 & 0.3 \\
\hline & B3 & 5.86 & 5.80 & 5.80 & 17.46 & 5.82 & 0.03 \\
\hline$\Sigma$ & & & & & & 18.16 & \\
\hline$\overline{\mathbf{X}}$ & & & & & & 6.05 & \\
\hline
\end{tabular}

Data organoleptik tekstur menunjukan bahwa pengambilan sampel jam 06.00-07.00, 11.00-12.00 dan 16.00-17.00 mendapatkan nilai di atas angka 6 , lebih rendah dari nilai organoleptik netral yaitu 7. Ini berarti dari nilai organoleptik tekstur, ikan sampel masih layak dikonsumsi.

\section{KESIMPULAN}

Berdasarkan hasil penelitian dapat disimpulkan yaitu sebagai berikut: 
1. Berdasarkan nilai rata-rata $\mathrm{pH}$, ikan Cakalang sampel masih layak dikonsumsi sampai jam 16.00-17.00 dari pedagang 1, 2 dan 3 , karena mendapat nilai yang cukup rendah.

2. Berdasarkan nilai rata-rata TVB-N, ikan Cakalang sampel masih layak dikonsumsi sampai jam 16.00-17.00 dari pedagang 1, 2 dan pedagang 3 , sebab belum melewati nilai ambang batas kesegaran.

3. Berdasarkan nilai organoleptik, ikan Cakalang sampel masih layak dikonsumsi sampai jam 16.00-17.00 dari pedagang 1, 2 dan 3, karena masih berada di atas angka 6.

4. Berdasarkan hasil uji nilai $\mathrm{pH}$, uji TVB-N dan uji organoleptik, ikan Cakalang yang dipasarkan di pasar Bersehati pada jam 06.00-07.00, 11.00-12.00 dan sampai pada jam 16.00-17.00, masih layak dikonsumsi karena belum melewati batas kesegaran.

\section{DAFTAR PUSTAKA}

Afrianto, E. dan Liviawati. 1989. Pengawetan dan Pengolahan Ikan. Penerbit kanisius Yokyakarta.

Harikedua, J., 1994 Pengantar Teknologi PHP Fakultas Perikanan UNSRAT Manado.

Jasumto. 2005. Teknik Penanganan Ikan. Jakarta: Penebar Swadaya.

Rompon, S., 2002. Tingkat kesegaran ikan Kakatua (Coolydon sp). Beberapa Pasar di Manado. Skripsi, FPIK UNSRAT. Manado.

Sediaoetama, A.D.; 1991; 1lmu Gizi untuk Profesi dan Mahasiswa; Dian Rakyat. Jakarta.

Soekarto, S. T. 1985. Penelitian Organoleptik. Untuk Industri Pangan dan Hasil Perikanan. Bharatara Karya Aksara. Jakarta.

Suwetja, I K. 1992. Metode Penentuan Mutu Ikan. Penentuan Kesegaran Jilid I. Fakultas Perikanan Universitas. Manado.

Suwetja, I K. J. Pongoh, M. Daloma; 2006; Penentuan Rigor Indeks, PH, dan Uji TVB-N Beberapa Jenis Ikan laut; Manado; paper; Fakultas Perikanan dan Ilmu Kelautan Universitas Sam Ratulangi.

Suwetja, I K. 2011. Biokimia Hasil Perikanan, buku. Di terbitkan Oleh Media Prima Aksara. Jakarta. 204h 